\title{
Constraints Confronted by Small Farmers in Achieving Livelihood Security in Shahpura Block of Jabalpur District (M.P.), India
}

\author{
Sabyasachi Pradhan*, A. K. Pande and Kamini Bisht \\ Department of Extension Education, JNKVV, Jabalpur, India \\ *Corresponding author
}

\begin{tabular}{l} 
Ke y w o r d s \\
$\begin{array}{l}\text { Livelihood, rural } \\
\text { areas, constraints, } \\
\text { suggestions, } \\
\text { average mean score }\end{array}$ \\
\hline Article Info \\
$\begin{array}{l}\text { Accepted: } \\
18 \text { May } 2020 \\
\text { Available Online: } \\
\text { 10 June } 2020\end{array}$ \\
\hline
\end{tabular}

A B S T R A C T
The present study was an effort to analyze the constraints faced by farmers and suggestions for achieving livelihood security in Shahpura block of Jabalpur district in Madhya Pradesh. Shahpura block comprises 220 villages, out of which 8 villages were selected randomly by using simple random sampling method. Then 15 small farmers were selected randomly from each selected village. Thus, altogether 120 farmers were included for the study. In the study constraints faced by small farmers related to livelihood security was assessed i.e. economic constraints got the first rank with 2.38 average mean score (AMS), followed by technological constraints (Rank 2, AMS 2.12), social constraints (Rank 3, AMS 2.08), constraints in input supply (Rank 4, AMS 2.04), constraint in policy support (Rank 5, AMS 2.02), constraints in extension support (Rank 6, AMS 1.94), and ecological constraints (Rank 7, AMS 1.65), respectively.

\section{Introduction}

Livelihood in rural areas is very erratic and risk hidden. Most developing countries in the world have a large population of small-holder farmers. Moreover, $75 \%$ of poor people live in rural areas of which 2.1 billion live on less than $\$ 2$ a day and 880 million on less than $\$ 1$ a day, and most depend on agriculture for their livelihoods (Mehta et al., 2010). Livelihood is defined as adequate stock and flow of food and cash with an individual or a family to meet its basic needs. Livelihood security then means secured ownership of, or access to, resources and income-earning activities, including reserves and assets to offset risks, ease shocks and meet contingencies (Chambers, 1988).

Agriculture is the mainstay of the Indian economy, as it constitutes the backbone of the rural livelihood security system. It is the core of planned economic development in India, as the trickle-down effect of agriculture is 
significant in reducing poverty and regional inequality in the country (Agarwal, 2007). A majority of these farmers are suffering from poverty and unemployment, which fails to achieve necessary households makes a living over time. The government policies and programs should be focused on small/marginal farmers and non-farm labourers and should be made available employment opportunities which will increase their income level, livelihood security and standard of living in rural areas (Jodha et al., 2018).

Providing sustainable livelihoods to the poor has been a major thrust area for development planners, policymakers and practitioners. Hence, in this study, an attempt was made to adumbrate the constraints faced by small farmers and suggestions for achieving livelihood security in Shahpura block of district Jabalpur.

\section{Materials and Methods}

The investigation was conducted in the Jabalpur district (23.10' N 79.59' $\mathrm{E}$ ) of Madhya Pradesh. The district comprises seven blocks namely Jabalpur, Panagar, Kundam, Patan, Shahpura, Majholi, and Sihora. Out of which, Shahpura block was selected purposively because of having maximum number of small farmers as compared to other blocks. The selected block, Shahpura comprises 220 villages, out of which 8 villages were selected by using a simple random sampling method. Then 15 small farmers were selected randomly from each selected village.

Thus, altogether 120 farmers were selected for the investigation. Data were collected through personal interviews using the pretested structured schedule to elicit both qualitative and quantitative data on the problem faced by small farmers in achieving livelihood security. The household interview was conducted with the principal decisionmaker of the family, especially on economic constraints, technological constraints, social constraints, constraints in input supply, constraint in policy support, constraints in extension support, and ecological constraints.

\section{Results and Discussion}

\section{Social constraints}

Social problem is location specific and mostly concerned with individuals in a social system. Groupism, non-cooperation, jealously, adverse socio-political interferences created hurdles for the farmers. Table 1 shows that lack of awareness about alternative vocation/enterprises having weighted mean 2.69 followed by traditional bend of mind (2.07), lack of consciousness of people (1.94) and lack of initiative or poor leadership (1.62) were major social constraints as reported by the respondents. The results are in accordance with Nishanka (2012), Khatun and Roy (2012) and Mohanty et al., (2013).

\section{Ecological constraints}

Crops grown in the field are influenced by various factors like soil climate, temperature, weather, rainfall, natural calamities, sunlight, and insect pest problems that vary from situation to situation.

Table 1 reveals that most of the respondents viewed low soil fertility having weighted mean 1.94 , followed by non-availability of conducive climate (1.66), presences of undulated land (1.58) and inadequate rainfall (1.42) were the major ecological constraints in order of their importance. The present finding is similar to the work of Nishanka (2012), Khatun and Roy (2012), Mohanty et al., (2013), Jodha and Dahiya (2018) Chouhan (2014) and Krishnaprasad (2005). 


\section{Economic constraints}

Capital is one of the important factors which influenced the livelihood security of farmers. Regarding economical constraints, the data in table 1 shows that poor economic condition of people having weighted mean 2.74 , followed by non-availability of agriculture credit (2.65), lack of reasonable support price of their produce (2.59), price fluctuation in the market throughout the year (2.50), high cost of transportation (2.22), lack of adequate facilities for processing (2.15) and high incidences of the intervention of middleman (1.83) were more important constraints that needed to be evaluated properly.

The results are in accordance with Nishanka (2012), Khatun and Roy (2012), Mohanty et al., (2013), Krishnaprasad (2005), Joshi et al., (2006), Swati (2016), Jodha and Dahiya (2018), Chouhan (2014) and Kumar et al., (2019).

\section{Constraints in input supply}

The availability of input supply and support services in easy access to farmers were other important areas of very often motivated individuals.

It was revealed from the data from table 1 that timely unavailability of labour having weighted mean 2.55, followed by Unavailability of required farm equipment (2.23), Unavailability of quality seeds (2.05), Unavailability of seed in time (1.71) and Unavailability of desirable variety (1.66) were major important factors for constraints in input supply in order of their importance.

The findings of the study are in accordance with Nishanka (2012), Mohanty et al., (2013), Krishnaprasad (2005), Joshi et al., (2006), Swati (2016), Jodha and Dahiya (2018), Chouhan (2014) and Kumar et al., (2019).

\section{Technological constraints}

Transfer of technology is another important dimension which enriches the knowledge of farmer that lead to motivating them to adopt better alternatives for the subsistence of their livelihood. Therefore an attempt was made to study the extension support constraint. Table 1 revealed that lack of in information about new technology in farming having weighted mean 2.65 followed by lack of knowledge about Govt. schemes for agriculture (2.44), lack of knowledge about control of pest \& diseases (2.15), lack of knowledge about required fertilizer for the crops (1.95) and Lack of knowledge about irrigation system (1.45) were major factors under technological constraints in order of their importance of the respondents. The findings of the study are in accordance with Nishanka (2012), Mohanty et al., (2013), Saha and Bahal (2010) and Chouhan (2014).

\section{Constraint in extension support}

Transfer of technology is another important dimension which enriches the knowledge of farmer that lead to motivating them to adopt better alternatives for the subsistence of their livelihood. It is observed from the table 1 that lack of cooperation among staff and people having weighted mean 2.56 followed by lack of guidance and supervision by field staff (2.28), insufficient training programme (1.94), lack of coordination among different department (1.85), irregular monitoring (1.58) and evaluation of extension support activities (1.46) were the important constraints faced by farmers under extension support. The finding is in line with the research work of Nishanka (2012), Mohanty et al., (2013) and Krishnaprasad (2005). It is found that higher importance was given to lack of cooperation among staff \& people and lower importance was given to the evaluation of extension activities. 


\section{Constraint in policy support}

The Govt. has restructured agricultural policy to provide adequate support to the farmers. The data in table 1 that depicts that lack of remunerative sale price having weighted mean 2.74 followed by lack of incentive support (2.43), lack of storage facilities (2.36), lack of credit facilities (2.25), lack of price support for their inputs (1.93), lack of crop insurance (1.26) and deficit budget allocation for agriculture (1.23) were the policy support constraints based on the importance of the respondents.

The present findings are in line with the research work of Nishanka (2012), Khatun and Roy (2012), Mohanty et al., (2013), Krishnaprasad (2005), Swati (2016), Jodha and Dahiya (2018) and Chouhan (2014).

Data presented in Fig.1 revealed that Above all, out of three major classified constraints, the economic constraints were consider to be the main concern for livelihood security with highest average mean score of 2.38 followed by technical constraints (2.12), social constraints (2.08), constraints in input supply (2.04), constraints in policy support (2.02) and constraints in extension support (1.94) whereas Ecological constraints were found to be placed at the lowest average mean score of 1.65 .

\section{Suggestion for achieving livelihood security}

The suggestion refers to an opinion about constraints that can be used as a solution to overcome or to minimize them. To develop a foolproof extension strategy, it is essential to seek the opinions of the respondents. The purse of a person decides the activities one has to take up or one can take up.

The constraints faced by them maybe sometimes imaginary and sometimes due to lack of coordination at different levels. Hence in this study, all the farmers were requested to offer their valued suggestions for eliminating the constraints. The respondents were requested to express their suggestions to overcome the constraints.

The frequency for each suggestion was calculated and then converted into a percentage. Later on, the rank was assigned. The suggestion receiving high percentage was considered as an important suggestion and the suggestion receiving low percentage considered as less important suggestion.

In this study numbers of constraints were found out and following suggestions if implemented by the farmers may lead to their progress. The data of Table 2 shows the suggestions given by respondents for achieving livelihood security.

Majority of the respondents (87.50\%) suggested that there should be support from non- government agencies on different programme followed by availability of credit to people in time $(81.66 \%)$, proper coordination and cooperation among people (80.00\%), timely availability of inputs (71.66 $\%)$, adequate transport facilities (68.33\%), training programme on package of practices of crops and vocations (63.33\%), training to the local leader for proper motivation to the people $(60.83 \%)$, demonstration of farmer fair on alternative livelihood enterprises $(60.00 \%)$, exhibition on farming and other vocational practices $(48.33 \%)$, technical guidance and supervision of extension agency (47.50\%), awareness programmes on alternative vocations for the farmers $(31.66 \%)$, establishment of processing mill for their product $(23.34 \%)$ and technical guidance on fertilizer application/ plant protection management/ weed management.The present findings are in line with the research work of Nisanka (2012). 
Table.1 Constraints faced by respondents

\begin{tabular}{|c|c|c|c|c|c|c|c|c|}
\hline SN & Constraints & 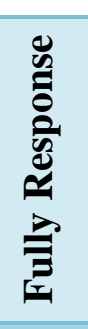 & 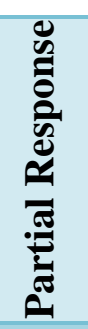 & 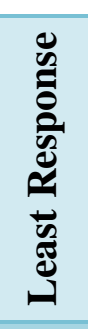 & 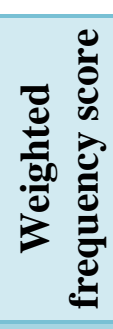 & 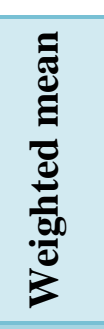 & $\begin{array}{l}\text { 䔍 } \\
\simeq\end{array}$ & 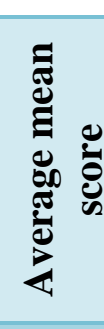 \\
\hline 1. & \multicolumn{8}{|l|}{ Social constraints } \\
\hline 1 & $\begin{array}{l}\text { Lack of awareness about alternative } \\
\text { vocation/enterprises }\end{array}$ & 83 & 37 & 0 & 323 & 2.69 & I & \multirow[t]{4}{*}{2.08} \\
\hline 2 & Lack of initiative or poor leadership & 7 & 61 & 52 & 195 & 1.62 & IV & \\
\hline 3 & Lack of consciousness of people & 9 & 95 & 16 & 233 & 1.94 & III & \\
\hline 4 & Traditional bend of mind & 42 & 45 & 33 & 249 & 2.07 & II & \\
\hline 2. & \multicolumn{8}{|l|}{ Ecological constraints } \\
\hline 1 & Presences of undulated land & 9 & 52 & 59 & 190 & 1.58 & III & \multirow[t]{4}{*}{1.65} \\
\hline 2 & Low soil fertility status & 26 & 61 & 33 & 233 & 1.94 & I & \\
\hline 3 & Inadequate rainfall & 4 & 43 & 73 & 171 & 1.42 & IV & \\
\hline 4 & $\begin{array}{l}\text { Non-availability of conducive } \\
\text { climate }\end{array}$ & 7 & 66 & 47 & 200 & 1.66 & II & \\
\hline 3. & \multicolumn{8}{|l|}{ Economical constraints } \\
\hline 1 & Non availability of argil. Credit & 79 & 40 & 1 & 318 & 2.65 & II & \multirow[t]{7}{*}{2.38} \\
\hline 2 & Poor economic condition of people & 89 & 31 & 0 & 329 & 2.74 & I & \\
\hline 3 & $\begin{array}{l}\text { High incidences of intervention of } \\
\text { middlemen }\end{array}$ & 7 & 86 & 27 & 220 & 1.83 & VII & \\
\hline 4 & $\begin{array}{l}\text { Lack of reasonable support price of } \\
\text { their produce }\end{array}$ & 64 & 53 & 3 & 311 & 2.59 & III & \\
\hline 5 & $\begin{array}{l}\text { Price fluctuation in the market } \\
\text { throughout the year }\end{array}$ & 73 & 45 & 2 & 300 & 2.50 & IV & \\
\hline 6 & $\begin{array}{l}\text { Lack of adequate facilities for } \\
\text { processing }\end{array}$ & 32 & 75 & 13 & 258 & 2.15 & VI & \\
\hline 7 & High cost of transportation & 41 & 65 & 14 & 267 & 2.22 & $\mathrm{~V}$ & \\
\hline \multicolumn{9}{|c|}{ Constraints in input supply } \\
\hline 1 & Unavailability of quality seeds & 35 & 56 & 29 & 246 & 2.05 & III & \multirow[t]{3}{*}{2.04} \\
\hline 2 & Unavailability of desirable variety & 16 & 48 & 56 & 200 & 1.66 & $\mathrm{~V}$ & \\
\hline 3 & Unavailability of seed in time & 12 & 62 & 46 & 206 & 1.71 & IV & \\
\hline
\end{tabular}




\begin{tabular}{|c|c|c|c|c|c|c|c|c|}
\hline 4 & $\begin{array}{l}\text { Unavailability of required farm } \\
\text { equipment }\end{array}$ & 37 & 74 & 9 & 268 & 2.23 & II & \\
\hline 5 & Timely unavailability of labour & 69 & 49 & 2 & 306 & 2.55 & I & \\
\hline \multicolumn{9}{|c|}{ 5. Technological constraints } \\
\hline 1 & $\begin{array}{l}\text { Lack of knowledge about required } \\
\text { fertilizer for the crops }\end{array}$ & 15 & 85 & 20 & 235 & 1.95 & IV & \multirow[t]{5}{*}{2.12} \\
\hline 2 & $\begin{array}{l}\text { Lack of knowledge about irrigation } \\
\text { system }\end{array}$ & 11 & 33 & 76 & 175 & 1.45 & $\mathrm{~V}$ & \\
\hline 3 & $\begin{array}{l}\text { Lack of knowledge about control of } \\
\text { pest \& diseases }\end{array}$ & 26 & 86 & 8 & 258 & 2.15 & III & \\
\hline 4 & $\begin{array}{l}\text { Lack of knowledge about Govt. } \\
\text { schemes for agriculture }\end{array}$ & 54 & 65 & 1 & 293 & 2.44 & II & \\
\hline 5 & $\begin{array}{l}\text { Lack of information about new } \\
\text { technology of farming }\end{array}$ & 78 & 42 & 0 & 318 & 2.65 & $\mathrm{I}$ & \\
\hline \multicolumn{9}{|c|}{ 6. Constraint in extension support } \\
\hline 1 & Insufficient training programme & 21 & 71 & 28 & 233 & 1.94 & III & \multirow[t]{6}{*}{1.94} \\
\hline 2 & $\begin{array}{l}\text { Lack of guidance \& supervision by } \\
\text { field staff }\end{array}$ & 42 & 70 & 8 & 274 & 2.28 & II & \\
\hline 3 & $\begin{array}{l}\text { Lack of coordination among different } \\
\text { dept. }\end{array}$ & 14 & 74 & 33 & 223 & 1.85 & IV & \\
\hline 4 & $\begin{array}{l}\text { Evaluation of extension support } \\
\text { activities }\end{array}$ & 11 & 34 & 75 & 176 & 1.46 & VI & \\
\hline 5 & Irregular monitoring & 18 & 34 & 68 & 190 & 1.58 & $\mathrm{~V}$ & \\
\hline 6 & $\begin{array}{l}\text { Lack of cooperation among staff \& } \\
\text { people }\end{array}$ & 68 & 52 & 0 & 308 & 2.56 & I & \\
\hline \multicolumn{9}{|c|}{ 7. Constraint in policy support } \\
\hline 1 & Lack of credit facility & 35 & 80 & 5 & 270 & 2.25 & IV & \multirow[t]{7}{*}{2.02} \\
\hline 2 & Lack of storage facility & 51 & 62 & 7 & 284 & 2.36 & III & \\
\hline 3 & Lack of price support for inputs & 12 & 88 & 20 & 232 & 1.93 & $\mathrm{~V}$ & \\
\hline 4 & Lack of crop insurance & 0 & 32 & 88 & 152 & 1.26 & VI & \\
\hline 5 & Lack of remunerative sale price & 89 & 31 & 0 & 329 & 2.74 & I & \\
\hline 6 & $\begin{array}{l}\text { Deficit budget allocation for } \\
\text { agriculture }\end{array}$ & 2 & 24 & 94 & 148 & 1.23 & VII & \\
\hline 7 & Lack of incentive support & 71 & 30 & 19 & 292 & 2.43 & II & \\
\hline
\end{tabular}


Table.2 Suggestions given by respondents for achieving livelihood security

\begin{tabular}{|c|c|c|c|c|}
\hline S. No & Statements & $\begin{array}{c}\text { Frequency } \\
(\mathrm{N}=120)\end{array}$ & $\begin{array}{c}\text { Percentage } \\
\%\end{array}$ & Rank \\
\hline 1 & $\begin{array}{l}\text { Proper coordination and cooperation } \\
\text { among people }\end{array}$ & 96 & 80.00 & III \\
\hline 2 & $\begin{array}{l}\text { Awareness programmes on alternate } \\
\text { vocations for the farmers }\end{array}$ & 38 & 31.66 & XI \\
\hline 3 & $\begin{array}{l}\text { Availability of credit to the people in } \\
\text { time }\end{array}$ & 98 & 81.66 & II \\
\hline 4 & Adequate transport facilities & 82 & 68.33 & V \\
\hline 5 & $\begin{array}{l}\text { Establishment of processing mill for } \\
\text { their product }\end{array}$ & 28 & 23.34 & XII \\
\hline 6 & $\begin{array}{l}\text { Technical guidance on fertilizer } \\
\text { application/ plant protection } \\
\text { management/ weed management }\end{array}$ & 22 & 18.34 & XIII \\
\hline 7 & $\begin{array}{l}\text { Training programme on package of } \\
\text { practices of crops and vocations }\end{array}$ & 76 & 63.33 & VI \\
\hline 8 & $\begin{array}{l}\text { Demonstration of farmer fair on } \\
\text { alternative livelihood enterprises }\end{array}$ & 72 & 60.00 & VIII \\
\hline 9 & $\begin{array}{l}\text { Exhibition on farming and other } \\
\text { vocational practices }\end{array}$ & 58 & 48.33 & IX \\
\hline 10 & Timely availability of inputs & 86 & 71.66 & IV \\
\hline 11 & $\begin{array}{l}\text { Technical guidance and supervision of } \\
\text { an extension agency }\end{array}$ & 57 & 47.50 & $X$ \\
\hline 12 & $\begin{array}{l}\text { Support from non-government agencies } \\
\text { on different programmes }\end{array}$ & 105 & 87.50 & I \\
\hline 13 & $\begin{array}{l}\text { Training to the local leader for proper } \\
\text { motivation to the people }\end{array}$ & 73 & 60.83 & VII \\
\hline
\end{tabular}

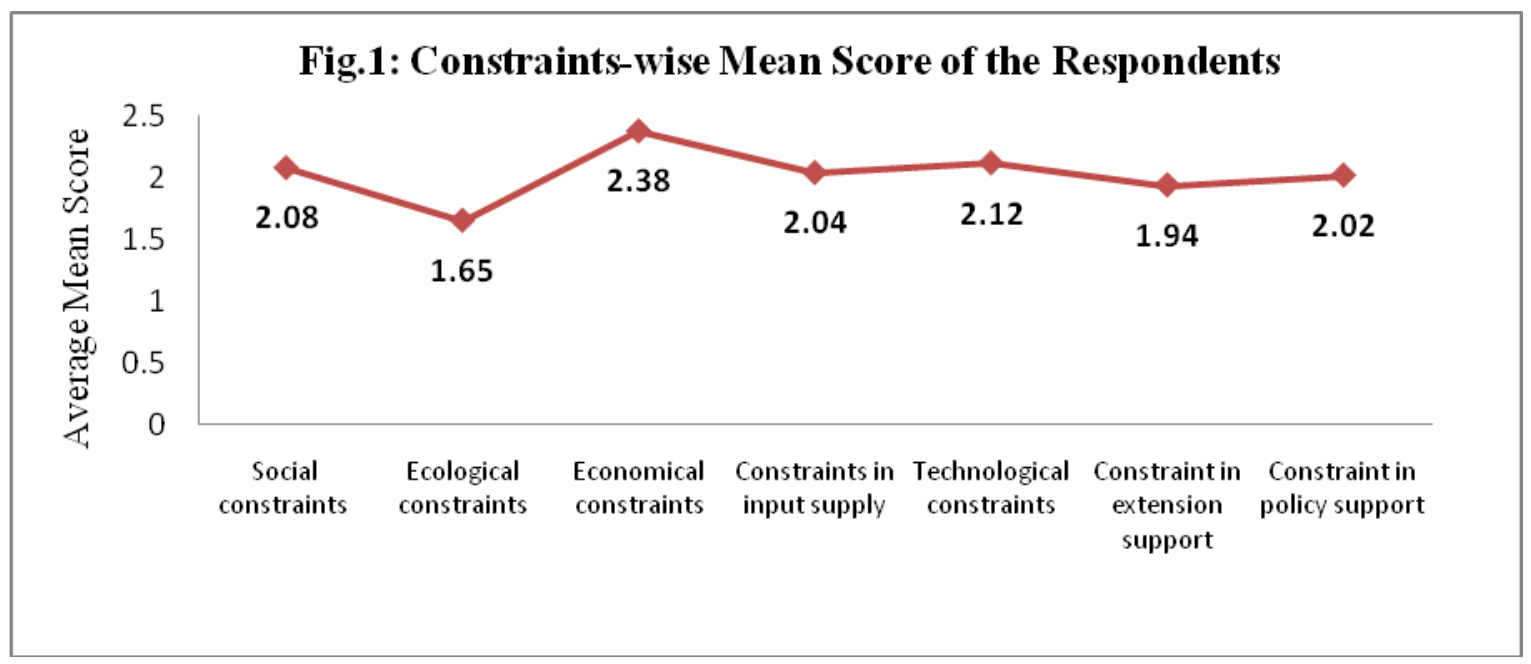

Fig.1 Constraints-wise mean score of the respondents 
The constraints in achieving livelihood security are many and diversified. The constraints differ from individual to individual based on the family requirement, socio-cultural variation, economic condition, etc. This study has unveiled many social, ecological, economical, input supply and support services, extension support, policy support, etc.

This requires quick redressal at appropriate levels for creating awareness among them for achieving livelihood security system. Keeping the problems of livelihood in mind, it can conclude that livelihood security is a need of time for proper coordination among people, support from non-government agencies, and availability of credit to the people is given more importance by the farmers. Secondly, there is a problem of transport, timely availability of inputs are the problems suggested by the respondents that need to be evaluated. There is a need for attention by policymakers towards the development of infrastructure and employment opportunities in the rural areas and improvement in the existing rural livelihood security system.

\section{References}

Agarwal, O. P. 2007. Cotton economy in India. https://wcrc.confex.com/wcrc/2007/tech program/P1780.HTM. Accessed 21 march 2020

Anonymous. 2011. Report of District Planning and Statistical Office, Jabalpur (M.P).

Chambers, R. 1988. Sustainable Rural Livelihoods: A Key Strategy for People, Environment and Development in $\mathrm{C}$. Conroy and M. Lituinoff, The Greening of AID, Earthscan. London.

Chaudhary, S. 2017. Is Agriculture Failing Rural India? https://blogs.grassroutes.co.in/2017/05/ 10/is-agriculture-failing-rural-india/.

Accessed 18 March 2020.

Chouhan, S. 2014. Problems and prospects of small and Marginal farmers in dharwad District: an economic analysis. M.Sc. (Ag) Thesis (unpublished). UAS, Dharwad.

Jodha, R. and Dahiya, M. 2018. Livelihood Problems of Small and Marginal Farm Families in Rural Areas of Haryana State. Int.J.Curr.Microbiol.App.Sci. 7(01): 1624-1629.

Jodha, R., Dahiya, M. and Singh, P. 2018. Farm families livelihood Problems: A research study in rural areas of Haryana state, India. Journal of Pharmacognosy and Phytochemistry. 7(3): 3243-3246.

Joshi, P.K. and Birthal, P.S. 2006. Diversification and its impact on smallholders: evidence from a study on vegetable production. Agricultural Economics Research Review. 19(2): 219-36.

Khatun, D. and Roy, B. C. 2012. Rural Livelihood Diversification in West Bengal: Determinants and Constraints. Agricultural Economics Research Review. 25(1): 115-124.

Krishnaprasad, T. 2005. A study on rural poverty and sustainable livelihood in agrarian sector of Andhra Pradesh. Ph.D. Thesis, Acharya N.G. Ranga Agricultural University, Hyderabad.

Kumar, V. H.M., Chauhan, N. B., Patel, D.D. and Patel, J. B. 2019. Predictive factors to avoid farming as a livelihood. Journal of Economic Structure. 8:10.

Mehta, S., Rupela, O., Bisht, S., Nayak, A. K. and Hegde, N. G. 2010. Improving the Livelihoods of the Resource-Poor Smallholder Farmers and Producers in Developing Countries: An Urgent Appeal for Action by GCARD. The Global Conference on Agricultural Research for Development (GCARD).

Mohanty, A. K., Lepch, B. and Kumar, A. 
2013. Constraints Analysis in Adoption of Vegetable Production Technologies for Livelihood Perspective of Tribal Farmers in North Sikkim. Indian Research Journal of Extension Education. 13(2): 51.

Nisanka, S. 2012. A study on alternate livelihood system for socio-economic Changes of dongriakondha tribe of rayagada district. Ph.D. Thesis, OUAT,
Bhubaneswar.

Saha, B. and Bahal, R. 2010. Livelihood Diversification pursued by Farmers in West Bengal. Indian Research Journal of Extension Education. 10(2): 1-9.

Swathi, G. 2016. A study on livelihoods of tribal farmers in andhrapradesh. Ph.D. Thesis Acharya N. G. Ranga Agricultural University. Guntur.

\section{How to cite this article:}

Sabyasachi Pradhan, A. K. Pande and Kamini Bisht. 2020. Constraints Confronted by Small Farmers in Achieving Livelihood Security in Shahpura Block of Jabalpur District (M.P.), India. Int.J.Curr.Microbiol.App.Sci. 9(06): 2108-2116. doi: https://doi.org/10.20546/ijcmas.2020.906.258 